Canadian University Music Review

Revue de musique des universités canadiennes

\title{
White Noise: Composition, Colonization, and Colour
}

\section{Geraldine Finn}

Volume 18, numéro 1, 1997

Crossing Borders: Interdisciplinary Studies by Canadian Scholars Franchir les frontières : études interdisciplinaires de chercheurs canadiens

URI : https://id.erudit.org/iderudit/1014821ar

DOI : https://doi.org/10.7202/1014821ar

Aller au sommaire du numéro

\section{Éditeur(s)}

Canadian University Music Society / Société de musique des universités canadiennes

\section{ISSN}

0710-0353 (imprimé)

2291-2436 (numérique)

Découvrir la revue

Citer cet article

Finn, G. (1997). White Noise: Composition, Colonization, and Colour. Canadian University Music Review / Revue de musique des universités canadiennes, 18(1), 66-83. https://doi.org/10.7202/1014821ar
Résumé de l'article

This paper examines the links between Western music, Western metaphysics, and Western imperialism. Taking Derrida's reading of "White Mythology" and "Violence and Metaphysics" as its point of departure, the paper explores the relationship between the theories and practices of musical composition formalized in Europe in the eighteenth and finalized in the nineteenth century, and the theories and practices of race, racial differentiation, and empire that coincide(d) with it.
All Rights Reserved (C Canadian University Music Society / Société de musique des universités canadiennes, 1997
Ce document est protégé par la loi sur le droit d'auteur. L'utilisation des services d'Érudit (y compris la reproduction) est assujettie à sa politique d'utilisation que vous pouvez consulter en ligne.

https://apropos.erudit.org/fr/usagers/politique-dutilisation/ 


\title{
WHITE NOISE: COMPOSITION, COLONIZATION, AND COLOUR ${ }^{1}$
}

\author{
Geraldine Finn
}

A pure white noise signal may only be produced by a generator called a white noise generator. ${ }^{2}$

The objective of this article is not just to establish links between the structures and rhetorics of race and the structures and rhetorics of functional tonality, but to re-inscribe the latter within and as the former, i.e., to re-write the text(s) of classical composition as practices of white supremacy. This re-writing of the classical texts of Western composition within and as a discourse of colonization and colour entails a sustained and systematic practice of (re)reading (re-citing). This article takes the quarrel between Jean-Jacques Rousseau (1712-1778) and Jean-Philippe Rameau (1683-1764) over the respective merits of melody and harmony as the essence and origin of music as its point of entry into this re-reading of the classical tradition, and Bizet's Carmen as an exemplification of what is at stake in their debate and of the violence of its resolution in favour of Rameau, i.e., in favour of harmony over melody and song.

The study draws on recent scholarship in alternative musicology which takes the interests and realities of class, sexuality, and gender into account in its analyses of the forms and structures of Western music(s), ${ }^{3}$ and extends them to include the interests and realities of race, the white European race, ${ }^{4}$ inviting

1 This article is a reworked and extended version of a paper first presented at the conference Border Crossings: Future Directions in Music Studies at the University of Ottawa, 8-11 March 1995; and then at the conference The Academy and Race: Toward a Philosophy of Political Action at Villanova University, March 1996. The reader should note that the term "colour" as used in this paper is not synonymous with "tone colour" or "timbre" - its specific meaning here will become clear from its useage within the article.

2Barry Truax, ed., The World Soundscape Project's Handbook for Acoustic Ecology (Burnaby, B.C.: World Soundscape Project, 1978), 152.

3 See, for example, Susan McClary, Feminine Endings: Music, Gender, and Sexuality, (Minneapolis: University of Minnesota Press, 1991) and Georges Bizet: Carmen, Cambridge Opera Handbooks (Cambridge: Cambridge University Press, 1992); Edward Said, Culture and Imperialism (London: Chatto and Windus, 1993); John Shepherd, Music as Social Text (Cambridge: Polity Press, 1991); Richard Leppert, The Sight of Sound: Music, Representation, and the History of the Body (Berkeley: University of California Press, 1993); Ruth Solie, ed., Musicology and Difference: Gender and Sexuality in Music Scholarship (Berkeley: University of California Press, 1993); Philip Brett, Elizabeth Wood, and Gary Thomas, eds., Queering the Pitch: The New Gay and Lesbian Musicology (London: Routledge, 1994).

4See McClary, Feminine Endings and Georges Bizet: Carmen, Leppert, The Sight of Sound, and Said, Culture and Imperialism for previous elaborations of the relationship between race and Western music which have influenced this paper: McClary's discussion of chromaticism in her essays on 
the reader to consider the implications of this for contemporary practices of Western music and its preservation and reproduction of its classical traditions - like Carmen - in particular.

\section{Harmony. Reduced to Its Natural Principles}

I begin with a citation from Jean Philippe Rameau's Treatise on Harmony Reduced to Its Natural Principles. Rameau is credited with having laid the foundations of the modern theory of Harmony in his treatise, in which he set forth the principles of key-centre, fundamental bass, and the roots and inversion of chords. ${ }^{5}$ So what he has to say is not without significance. I have italicized those words which are most revealing of his embeddedness in, his indebtedness to the hierarchical oppositions which organize Western metaphysics and its privileging of reason and abstraction over experience and the evidence of sensation, and which are discussed in more detail in subsequent sections of this article.

However much progress music may have made until our time, it appears that the more sensitive the ear has become to the marvellous effects of this art, the less inquisitive the mind has been about its true principles. One might say that reason has lost its rights, while experience has acquired a certain authority.

The surviving writings of the Ancients show us clearly that reason alone enabled them to discover most of the properties of music. Although experience still obliges us to accept the greater part of their rules, we neglect today all the advantages to be derived from the use of reason in favour of purely practical experience.

Even if experience can enlighten us concerning the different properties of music, it alone cannot lead us to discover the principle behind these properties with the precision appropriate to reason. Conclusions drawn from experience are often false, or at least leave us with doubts that only reason can dispel. How, for example, could we prove that our music is more perfect than that of the Ancients, since it no longer appears to produce the same effects they attributed to theirs? ... But if through the exposition of an evident principle, from which we then draw just and certain conclusions, we can show that our music has attained the last degree of perfection and that the Ancients were far from this perfection ... we shall know where we stand. ${ }^{6}$

Though we can judge the effects of music only through the sensations of our organs of hearing, our mind can grasp its properties only with the aid of reason.

Since experience offers us a large number of chords, while reason assembles them all into a single one, we should prefer the latter in our judgments.

Carmen; Leppert's discussion of the role of music in eighteenth-century portraits of the British in India in privileging the values of Harmony, Unity and Order, and thus establishing the superiority of the colonizers over the colonized, in "Music, Domesticity, and Cultural Imperialism" (pp. 91-117); and Said's description of the "Empire at Work" in Aida (pp. 111-32).

5 Collins Encyclopedia of Music (London: Collins, 1976), 443.

6Jean-Philippe Rameau, Treatise on Harmony, trans. Philip Gossett (New York: Dover, 1971), 33. 
In music, experience alone is incapable of convincing us. But reason may supplement it.

Music is subordinate to arithmetic. ${ }^{7}$

\section{White Mythology}

Any expression of an abstract idea can only be an analogy. By an odd fate, the very metaphysicians who think to escape the world of appearances are constrained to live perpetually in allegory. A sorry lot of poets, they dim the colours of the ancient fables and are themselves but gatherers of fables. They produce white mythology. 8

What Jacques Derrida is describing here as "white mythology" is Western metaphysics' insistence on abstraction, i.e., on the abstraction of truth, reality, ideas, and values from sensory experience, and from any representation of truth, reality, ideas, and values in its terms, i.e., in terms of experience, sensation, or concrete particulars. As in the citation from Rameau which subordinates (music) sensation, experience, and the body to (arithmetic) intelligibility, reason, and the mind: "Though we can judge the effects of music only through the sensations of our organs of hearing, our mind can grasp its properties only with the aid of reason ... Music is subordinate to arithmetic."

Obviously, Derrida is himself drawing an analogy here between the wouldbe transparency of the no-myth mythology of Western metaphysics (Western rationality) and the whiteness of white light: "light, such as daylight, containing all wavelengths of the visible spectrum at normal intensities so that no colouration is apparent." So that no colouration is apparent. White light does not draw attention to itself as light, i.e., to its own materiality, substance, or sensibility, but as light (as the essence of light) draws attention to the materiality, substance, and sensibility of others: their shape, texture, and colour, the specificity of their sensory configuration. Just as the white mythology of Western metaphysics does not draw attention to itself as mythology, metaphor, or physis, but rather, as the (white) light of Reason, illuminates the mythology, the metaphoricity, the physis of others. And, like the sun of Plato which is one of its founding metaphors (more on founding metaphors later), posits its own metaphysical space, the space of its own mastery, as the space of en-lighten-ment beyond physis, and beyond metaphor itself. So that no colouration is apparent.

This systematic blanching of Western metaphysics (and the science which coincides with it) is most explicit in one of the "illustrations" Derrida draws from Bachelard's La formation de l'esprit scientifique (1938) which articulates

7 Ibid., 47-48.

8 Anatole France, cited by Jacques Derrida, "White Mythology: Metaphor in the Text of Philosophy," in Margins of Philosophy, trans. Alan Bass (Chicago: University of Chicago Press, 1982), 213.

9H. J. Gray and Alan Isaacs, eds., Dictionary of Physics (London: Longman, 1991), 611. 
its own call for non-metaphoricity in terms of the metaphor of musical composition which is the topic of this paper:

The danger of immediate metaphors in the formation of the scientific spirit is that they are not always passing images; they push toward an autonomous kind of thought; they tend to completion and fulfilment in the domain of the image. $^{10}$

A psychoanalysis of objective knowledge then, must set itself to blanching, if not erasing, these naive images. When abstraction will have achieved this, it will be time to illustrate rational schemas. In short, the initial intuition is an obstacle to scientific thought; only an illustration working beyond the concept, putting a bit of color on the essential characteristics, can aid scientific thought. ${ }^{11}$ (my italics)

But Derrida is also (re)marking the racial specificity of Western metaphysics when he describes it as white mythology: (re)marking it as the mythology of the white man who posits himself as the universal "one," abstracted from all particular embodiments (so that no colouration is apparent) whose other, the other of the truth of his en-lighten/whiten-ment, is always a racialized other, i.e., an embodied, un-enlightened/whitened, and therefore opaque, obscure, darkened other, an other in and of the dark.

Metaphysics - the white mythology which reassembles and reflects the culture of the West: the white man takes his own mythology, Indo-European mythology, his own logos, that is, the mythos of his idiom, for the universal form of that he must still wish to call Reason. ${ }^{12}$

The palimpsest of this sensible figure of the white man, i.e., of his specific embodiment as white (as much "white" as the "black" man is "black"), ${ }^{13}$ at once sheltered in and erased by the bright light of Reason, is more exposed in the original formulation of white mythology from which Derrida drew his own metaphor, that of Anatole France, who described our metaphysicians not as white, but as anaemic.

10Gaston Bachelard, La formation de l'esprit scientifique (Paris: Corti, 1938), 81, cited in Derrida, "White Mythology: Metaphor in the Text of Philosophy," 259.

11 Bachelard, La formation de l'esprit scientifique, 78, cited by Derrida, ibid.

12Derrida, "White Mythology: Metaphor in the Text of Philosophy," 213.

13 "White" and "black" here are to be understood as catachresis, that is, in the sense given to the term by Gayatri Spivak (The Post-Colonial Critic: Interviews, Strategies, Dialogues, ed. Sara Harasym [New York: Routledge, 1990], 104, 154). Catachresis means that there is no literal referent for a particular word, no "true" example of that which it purports to name; in this case, no "true white man" who would actually stand for the ideals in terms of which he is mobilized. ("He" is also catachrestic in this context, referring as it does to an ideal which is posited as singular [i.e., universal] and masculine [i.e., neutral] but which both includes and excludes the feminine and the many according to context, intention, or effect.) 
A sorry lot of poets, they dim the colours of the ancient fables, and are themselves gatherers of fables. Their output is mythology, an anaemic mythology..$^{14}$

This anaemic refers us much more directly to the (originating) body of the truth of Western metaphysics - which is supposed to originate elsewhere than the body - as an anaemic body, one in which no colouration is apparent, a bloodless, sickly, weak, white body for which blood is always other: the blood of an other, or the sacrificial blood (blood as other) of the other in self, i.e., blood which must be bled from, to maintain the integrity of, the (would-be) universal (white) One. Blanched from its essence, as Bachelard might say.

\section{The Violence of White}

In an earlier essay on "Violence and Metaphysics," 15 Derrida particularizes the body of Western metaphysics not in terms of its whiteness but in terms of the opposition between Greek and Jew, its opposition of Greek (philosopher) to Jew (prophet): its insistence on the purity of its own origins in ancient Greece and on an ontology inherited from its philosophers. A genealogy, an ontology, which Derrida elaborates (following Emmanuel Levinas) in terms of the violence of its operations and effects: specifically, its totalitarian demand that multiplicity be included in, subjected to, the domination of the One; its confinement of the other to the Same. ("Since experience offers us a large number of chords, while reason assembles them all into a single one, we should prefer the latter in our judgments.") A totalitarian demand for unity which Derrida elaborates in terms of the violence of light and the imperialism of theoria.

There is a soliloquy of reason and a solitude of light. Incapable of respecting the Being and meaning of the other ... the entire philosophical tradition in its meaning and at bottom, would make common cause with oppression and with the totalitarianism of the same. The ancient complicity between theoretical objectivity and technico-political possession. ${ }^{16}$

Derrida describes this totalitarian ontology of Western metaphysics which reduces the other to the same and multiplicity to the One, as a tautology, an egology (again following Levinas), which has always neutralized the other "in every sense of the word."17

The neutral thought of Being neutralizes the Other as a being: "Ontology as first philosophy is a philosophy of power," a philosophy of the neutral, the tyranny of the state as an anonymous and inhuman universality. ${ }^{18}$

14France, cited by Derrida, "White Mythology: Metaphor in the Text of Philosophy," 213.

15Derrida, "Violence and Metaphysics," in Writing and Difference, trans. Alan Bass (Chicago: University of Chicago Press, 1978), 79-153.

16 Ibid., 91.

17 Ibid., 96.

18 Ibid., 97. Derrida is citing Totality and Infinity by Emmanuel Levinas, p. 46. 


\section{Tonality - Classical-style}

The source of harmony subsists in a single sound. The fundamental sound, i.e., the source, uses its octave as a second term to which all intervals generated by its division should be related; this emphasizes that the fundamental sound is their beginning and their end. ${ }^{19}$

There is only one chord ... The source of all chords resides in a single sound. ${ }^{20}$

The tonal system, particularly the natural (major) one, could be seen as a sort of higher collective order, similar to a state, based on its own social contracts by which the individual tones are bound to abide ... The relationships of the tone are established in its systems. If the egotism of a tone expresses itself in the desire to dominate its fellow-tones rather than be dominated by them (in this respect, the tone resembles a human being), it is the system which offers to the tone the means to dominate and thus to satisfy its egoistic urge. A tone dominates the others if it subjects them to its superior vital force. In this sense, a system resembles, in anthropomorphic terms, a constitution, regulation, statute, or whatever other name we use to grasp conceptually the manifold relationships we enter. ${ }^{21}$

Heinrich Schenker (1868-1935) is unashamedly metaphorical in his descriptions of the hierarchical order of Western harmony and the singularity and superiority of its system (as we shall see again later). He is not an arbitrary or eccentric choice here. For he is the current darling of hard-core musical analysis in North America, analysis which shows its muscle by generating graphs of abstract musical structure based on Schenker's theory of the origins and source of music classical-style. More recent accounts of tonality describe similar systems of singularity and hierarchy in terms more successfully blanched than Schenker's of those naive images (of domination and state control, in this case) which Bachelard believed interfered with the accomplishments of objective thought, but not for all that secured against the passing images of metaphor.

The classical style subordinated all details to the one central ideal of organic growth, in which mere effects had no place unless they were in definite and logical relation to the whole. ${ }^{22}$

Tonal harmony is in fact the type of musical language in which the most transparent logic reigns, in which logic is truly made flesh, and becomes, as proof of the absolute transcendence of individual reason, the object of unique and irreplaceable pleasure. ${ }^{23}$

19 Rameau, Treatise on Harmony, 52.

20 Ibid., 40.

21 Heinrich Schenker, Harmony, ed. Oswald Jonas, trans. Elisabeth Mann Borgese (Chicago: University of Chicago Press, 1954), 84.

22Paul Henry Lang, Music in Western Civilization (New York: Norton, 1941), 711.

23Henri Pousseur, Fragments théoriques I sur la musique expérimentale (Brussels: Éditions de l'Institut de sociologie, Université libre de Bruxelles, 1970), 87. 
The tonic of a key, the centre of the tonal universe, determines a complete hierarchy of notes in which each note functions as an individual or as part of a chord; the tonic is home base, the static point, the point of rest. ${ }^{24}$

Tonality is a hierarchical arrangement of the triads based on the natural harmonics of a note. ${ }^{25}$

A decision made against the chaos of pitch. ${ }^{26}$

Loyalty to a tonic in the broadest sense of the word. ${ }^{27}$

\section{Philosophy of the Site}

By another paradox the philosophy of the neutral communicates with a philosophy of the site, of rootedness, of pagan violence, of ravishment, of enthusiasm, a philosophy offered up to the sacred, that is, to the anonymous divinity, the divinity without the Deity. ${ }^{28}$

In the Critique of Pure Reason Kant describes metaphysics as an "edifice" erected on secure "foundations" laid on the most stable "ground." This architectural metaphor - of foundations, erection, and ground (of building, thinking, and dwelling to use Heidegger's terms) - is constitutive of Western metaphysics which cannot be thought, cannot think itself, without it, but which nevertheless subordinates it as metaphor in deference to some higher abstract truth (of reason, mind, mathematics, logos, nature, or spirit) to which the architectural metaphor is (posited as) secondary (supplement, ornament, or, as in the case of Bachelard, illustration) ${ }^{29}$

Thus hierarchy, the vertical hierarchy of foundation, ground, structure, ornament, is constitutive of Western metaphysics by virtue of its founding metaphor, architecture, the metaphor of foundations. A siting of philosophy, a philosophy of the site, in/at which building and belonging intersect articulating a mastery of space, of place, a determination of what does and does not belong: a logic of inhabitation, generation, rootedness, violence and the law. ${ }^{30}$ And, by another paradox as Derrida suggests, "a philosophy offered up to the sacred, that is, to the anonymous deity, the divinity without the Deity."

24Bennett Reimer and Edward Evans, The Experience of Music (Englewood Cliffs, N.J.: PrenticeHall, 1972), 52.

25Charles Rosen, The Classical Style: Haydn, Mozart, Beethoven (New York: Norton, 1972), 23.

26Richard Norton, Tonality in Western Culture: A Critical and Historical Perspective (University Park, Penn.: Pennsylvania State University Press, 1984), 4, 21.

27Willi Apel, Harvard Dictionary of Music, 2nd ed. (Cambridge, Mass: Harvard University Press, 1977), 855.

28Derrida, "Violence and Metaphysics," 97.

29See Mark Wigley, The Architecture of Deconstruction: Derrida's Haunts (Boston: MIT Press, 1993) for an inspired elaboration of this point with reference to deconstruction and the work of Derrida.

$30 \mathrm{~A}$ violence and a law which is always already domestic, according to Derrida (see Wigley, The Architecture of Deconstruction, chap. 4, for details): "Metaphysics is more than the disguising of this domestic violence that in turn represses the fundamental strangeness of the house" (ibid., 109). Carmen (re)presents (among other things) the unveiling of this domestic violence constitutive of Western metaphysics and the tonality articulated in its terms, the "realism" of the repressions entailed by its principle of "loyalty to the tonic in the broadest sense of the word" (Apel, Harvard Dictionary of Music, 855 ). 
The same logic of siting (and the sacred) and of building (and belonging) informs the theorizing (the consecration) of harmony classical-style.

A principle on which everything is founded cannot be established too firmly; to lose sight of it for a moment is to destroy it. ${ }^{31}$

The essence of all these types of music is causal relationship achieved by the grouping of many small units into larger ones and finally into a great system of architecture. ${ }^{32}$

Orchestration and tone colour serve to solidify and set off the architectonic construction. ${ }^{33}$

The theory of harmony presents itself to me as a purely spiritual universe, a system of ideally moving forces, born of Nature or of art. ${ }^{34}$

The musician must never sacrifice and destroy the primary element of his art, which is the diatonic system, for the sake of a merely secondary element, that is, chromatic change ... Where the composer unmistakenly reveals his intention to ruin the diatonic system, we have not only the right but even more the moral duty to resent the deceit against our art and expose the lack of artistic instinct which manifests itself here even more drastically. ${ }^{35}$

\section{Everything Is Simple, Familiar, Precise}

Everything is simple, familiar, precise, true, and accurate. Nothing is simpler or more familiar than the natural progression of numbers and the arithmetic operations which alone suffice as proof here; nothing is more precise than all the properties of harmony included in the senary number (i.e., in the scenario); nothing is truer or more accurate than finding the source everywhere in the unit, as we shall explain. ${ }^{36}$

Everything that Derrida says about the white mythology of Western metaphysics - as a philosophy of the One, of the neutral, of the site, of the sacred can be applied, as some of these citations already suggest, to the theorizing of music within it and to the theorizing of functional tonality in the eighteenth and nineteenth centuries, the common practice period, in particular: the privileging of the abstract over the concrete, of Reason over experience, of the One over the many; the demand that multiplicity be included in, subjected to, the domination of unity: the unity of the fundamental tone, the "root" of any chord; the unity of the chord "generated" from or "built" upon it; the unity of the tonal system itself - the diatonic system, "the real and most solemn truth of Nature" according to Schenker, ${ }^{37}$ "the spiritual and superior unit." 38 A unity whose

31 Rameau, Treatise on Harmony, 59.

32Lang, Music in Western Civilization, 1020.

33 Ibid., 711.

34 Schenker, Harmony, 25.

35 Ibid., 290.

36Rameau, Treatise on Harmony, 25.

37 Schenker, Harmony, 53.

38 Ibid., 294. 
principal structure, logic, and ground is posited as both foundational and given; at once ideal and real; rooted in both Nature (the natural overtone system) and Number (ratio, proportion, arithmetic). Thus, as neutral and so, paradoxically, divine.

Though the descriptions and definitions of the system and principles of music rely on metaphor as we have seen - figures of hierarchy and home, root, source, centre, and state - the system and its music are nevertheless posited as and understood to be socially, materially, and politically neutral: merely the expression, articulation, or reflection of abstract principles of reason and right, or reality itself (the natural overtone system). Thus, Western musicology ${ }^{39}$ assumes and (re)articulates the same metaphysical pretensions of Western philosophy: to objectivity, transparency, universality, rationality, necessity, teleology, and the finality (the irreducibility) of (its) origins and ends.

More precisely what Western musicology shares with Western metaphysics are the following:

1. A preoccupation with foundations, authority, stability, and control: "the desire for a firm and ultimate ground, a terrain to build on," 40 characteristic of a philosophy of the site.

2. A corresponding denial of its own relationship to that ground, i.e., a disavowal of the material specificity of its own embodiment, its own specific body, its own agency in the production, construction, and ordering, the siting, of the ground it claims to merely discover, the site it merely re-cites/re-sights. Musical knowing, musical creativity, for example, is posited within this tradition, not as a function of a body that moves and makes sound, or of a situated and fully embodied ear that hears, but as the accomplishment of a disembodied (universal) $\mathrm{L} / \mathrm{eye}^{41}$ (a cogito, a beam of white light) that writes music, i.e., that makes music by writing and hears what is written with the mind's eye. As in the following, for example:

Harmony is the art of writing successive chords for voices or instruments ... To make satisfactory progress in harmony, the student should learn to hear what he writes ... He will ultimately acquire tonal vision, or ability to hear with the eye ... All experiments with the eye should be checked afterwards at the keyboard ... Exercises in harmony should never be worked at the keyboard, although the student should play them afterwards to hear the musical result of his work. ${ }^{42}$ (my italics)

39 "Here we may think both of the theory of musicology as a discipline and of music theory in the more usual sense in which we recognize it as an important tool of musicology" (Don Randel, "The Canons in the Musicological Toolbox," in Disciplining Music: Musicology and Its Canons, ed. Katherine Bergeron and Philip Bohlman [Chicago: University of Chicago Press, 1992], 11).

40Derrida, "Violence and Metaphysics," 224.

41 See Finn, "The Pornographic Eye/I," in Why Althusser Killed His Wife: Essays on Discourse and Violence [Atlantic Highland, N.J.: Humanities Press, 1996], 34-49, for a systematic critique of the constitutive duplicity and sexism of this disembodied I/eye, the would-be spectator-subject of Western philosophy and pornography alike.

42Frederick Harwood, The Basis of Harmony (1948), 3. 
3. A totalitarian logic of domination, hierarchy, and the law (a subordination of all tones to the tonic and the dominant of its system) such that "the ... entire tradition in its meaning and at bottom would make common cause with oppression and with the totalitarianism of the same." 43

\section{The Fabulous Scene}

White mythology - metaphysics has erased within itself the fabulous scene that has produced it, the scene that nevertheless remains active and stirring, inscribed in white ink, an invisible design covered over in the palimpsest. ${ }^{44}$

Contemporary scholars of alternative musicology 45 have uncovered the fabulous scenes of patriarchy, industrial and mercantile capitalism, and bourgeois hegemony inscribed within the no-myth mythologies of Western composition classical-style, and the very particular concrete material interests governing the would-be universality and neutrality of its forms and structures, its "loyalty to a tonic in the broadest sense of the word." What I would like to add to that list, and perhaps even privilege, are the governing interests of race, of the white European race in particular and its interest in domination, colonization and Empire.

My original point of departure for this particular insight and subsequent research (into the implicit and explicit racialization of Western composition classical-style) was Derrida's reading of Rousseau's Essay on the Origin of Languages in Which Something Is Said about Melody and Musical Imitation, ${ }^{46}$ of which the last eight chapters (12-20) are devoted to a defense of Melody as origin and essence of music, against similar claims made on behalf of Harmony by Jean-Philippe Rameau. This debate between Rousseau and Rameau will serve, therefore, as my point of entry into an elaboration of the theory and practice of Western music classical-style as White Noise, i.e., as white mythology, the mythology of White, of the neutral, the transparent, the One, which is at once the mark and the mask of the specificity of White domination. But before entering into the specificities of this debate in any detail let me first remind you of the "fabulous scene that has produced it ... That nevertheless remains active and stirring, inscribed in white ink, an invisible design covered over in the palimpsest." The scene is, of course, the eighteenth century:

1. It is the Age of En-lighten-ment: of a discourse of Reason, Rights and Man; of Liberty, Equality, and Fraternity; in which light functions as the dominant metaphor, the metaphor of domination (as Derrida argues in "The Violence of Light" in "Violence and Metaphysics").

43Derrida, "Violence and Metaphysics," 91.

44Derrida, "White Mythology: Metaphor in the Text of Philosophy," 213.

45 See note 3.

46Derrida, "Genesis and Structure of the Essay on the Origin of Languages," in Of Grammatology, trans. Gayatri Chakravorty Spivak (Baltimore: Johns Hopkins University Press, 1974), 165-268. 
2. It is the height of the slave trade - the trading of West Africans by Europeans to their colonies in the Americas. Indeed, the dates which mark the beginning and the end of slavery in North America: 1619 when the first twenty negroes were brought to Jamestown, Virginia as bondsmen to English settlers, to the Emancipation Proclamation of 1863, are roughly coincident with the dates used by some writers to designate the common practice period of functional tonality in Western music: 1600 and 1910.47

3. It is a time of corresponding debates within and among Church, State, and Science over the origin and significance of the blackness of Africans: their place in the Great Chain of Being; their proper classification as genus, species or type; their lineage; and the corresponding rights and wrongs of their enslavement. These debates, in turn, coincide with a whole series of philosophies of origins: of language, society, politics, of "Man" himself. ${ }^{48}$

4. It is a period of increasing fascination with and exoticization of distant lands and their peoples; exemplified by Rousseau's hypostatization of the noble savage and the state of nature, by Rameau's representation of the peoples of Turkey, Peru, Persia, and a North American forest as Les Indes galantes, the title of an opera-ballet.

5. These in their turn coincided with the emergence of increasingly sophisticated "scientific" theories of racial difference drawing on archaeology and philology as well as the observation of types.

6. As well as disputes over the colour of ancient Greece: over the genealogy of its civilization (how much of it was derived from its colonization by the Egyptians and the Phoenicians, for example), and thereby over the colour, the racial origins, of European civilization itself. ${ }^{49}$

Here we have a conjunction of interests and debates which culminated in, amongst other things: the American Declaration of Independence (1776); the French Revolution (1789); the establishment of the Committee for the Abolition of the Slave Trade in England (1787); the movement to resettle American blacks in Sierre Leone (1787); the publication of Kant's Critique of Judgement (1790); and finally the resolution and/or stabilization of some of these debates in the greater excesses of nineteenth century imperialism, romanticism, and scientific racism, including the European subjugation of Egypt, successful whitening of Greece, and corresponding blackening of the Jews. And, in music, the institutionalization, normalization and naturalization of functional tonality (Rameau's Principles of Harmony), as the supreme achievement of Western civilization, "a decision made against the chaos of pitch."

47Christopher Small, Music, Society, Education (Englewood Cliffs, N.J.: Prentice-Hall, 1977), 11. 48 See Michael Banton, Racial Theories (Cambridge: Cambridge University Press, 1987), and Emannuel Chukwudi Eke, ed., Race and the Enlightenment: A Reader (Oxford: Blackwell, 1997) for details and examples.

49Martin Bernal, Black Athena: The Afroasiatic Roots of Classical Civilization, vol. 1, The Fabrication of Ancient Greece, 1785-1985 (New Brunswick, N.J.: Rutgers University Press, 1987). 


\section{The Properties of Music}

Music is generally divided into harmony and melody, but we shall show in the following that the latter is a part of the former and that a knowledge of harmony is sufficient for a complete understanding of all the properties of music. ${ }^{50}$

The quarrel between Rameau and Rousseau over the respective claims of Melody and Harmony to (be considered) the essence of music itself is a quarrel over origins, a family quarrel over musical primogeniture: melody and song, or harmony and proportion; the spontaneity of speech (parole), or the structure of language (langue); experience or reason; practice or principle. A quarrel which is ultimately resolved in favour of Rameau, i.e., in favour of Harmony (reason, proportion, principle, structure) and even more precisely in Schenker's system in favour of the Perfect Fifth: "the fifth enjoys among the overtones, the right of primogeniture, so to speak." 51

Like all family quarrels, it is a quarrel over property, propriety and proper names: the properties of music and their proper place in the hierarchy of musical composition: foundation, ground, structure or ornament; source or supplement; fundamental or accidental to the integrity, the identity, the essential "musicality" of a work. Rousseau responds to Rameau, for example, in the following terms:

Every sense has its proper realm. The realm of music is time, that of painting is space. To multiply the number of sounds heard all at once ... (as in harmony) ... is to alter their economy, it is to substitute the eye for the ear. ${ }^{52}$

By itself a sound has no absolute character by which it might be recognized ... It is neither tonic, nor dominant, nor harmonic, nor fundamental; for all of these properties are only relationships ... every sound changes its rank and position in the system as the system changes in degree. ${ }^{53}$

It is, correspondingly, a quarrel over genealogy and generation, over succession and success, over lineage, location, and the (its) law. Over roots, racine, and thus over race:

Once melody was forgotten ... form, mode, scale, everything acquired a new complexion: harmonic succession came to determine the sequence of parts. Once this sequence had usurped the name of melody, it indeed became impossible to fail to recognize its mother's features in this new melody. ${ }^{54}$ (my italics)

50Rameau, Treatise on Harmony, 3.

51 Schenker, Harmony, 26.

52 Jean-Jacques Rousseau, The First and Second Discourse with the Replies to Critics, and Essays on the Origin of Languages, ed. and trans. Victor Gourevitch (New York: Harper and Row, 1986), 286. Cf. Harwood, cited earlier in this article.

$53 \mathrm{Ibid} ., 286$.

$54 \mathrm{Ibid} ., 293$. At stake in the quarrel, as Rousseau's comments here suggest, are the respective rights and privileges of matrilineal versus patrilineal descent, settled as conclusively in favour of the father 
And it is conducted entirely within the terms of the structured oppositions which articulate the closure of Western metaphysics, "the white mythology which reassembles and reflects the culture of the West" so that no colouration is apparent. The oppositions between, for example:

$\begin{array}{lll}\text { Concrete } & \text { and } & \text { Abstract } \\ \text { Contingent } & \text { and } & \text { Necessary } \\ \text { Particular } & \text { and } & \text { Universal } \\ \text { Many } & \text { and } & \text { One } \\ \text { Body } & \text { and } & \text { Mind } \\ \text { Sensation } & \text { and } & \text { Rationality } \\ \text { Heart } & \text { and } & \text { Head } \\ \text { Passion } & \text { and } & \text { Precision } \\ \text { Practise } & \text { and } & \text { Principle } \\ \text { Experience } & \text { and } & \text { Reason }\end{array}$

In the context of music these oppositions are articulated as and in terms of the oppositions between:

$\begin{array}{lll}\text { song } & \text { and } & \text { structure } \\ \text { voice (voix) } & \text { and } & \text { string (chord) } \\ \text { ear } & \text { and } & \text { eye } \\ \text { time } & \text { and } & \text { space } \\ \text { movement } & \text { and } & \text { placement } \\ \text { speaking } & \text { and } & \text { writing } \\ \text { accent } & \text { and } & \text { articulation } \\ \text { spacing } & \text { and } & \text { interval } \\ \text { personality } & \text { and } & \text { tonality } \\ \text { difference } & \text { and } & \text { derivation } \\ \text { addition } & \text { and } & \text { division }\end{array}$

At the same time, the quarrel re-plays, re-articulates, the ancient quarrel (discussed by Derrida in "Violence and Metaphysics") between poetry and philosophy, Jew and Greek (eschatology and teleology) already referred to in section 3. Between an understanding of and engagement with language, in this case music, as originary (as difference): in which there is no return to the same, in which one ventures outside oneself to the unforeseeable, which does not pass through the neutral element of the universal and respect for the law; 55 and the hypostasis of an original language, or music (in this case the diatonic system), in which a logos, a law, is posited as both present and determining, and which unfolds as the determinate structure of langue or music itself.

Finally, it is a quarrel over the place of colour - of sensation and experience, of the body and blood - in Western music: ornament or ground, origin or accident, fundamental or secondary. And over the whiteness, i.e., the 
neutrality, the rationality, the universality, of tonality classical-style (the style formalized by Rameau) in particular.

This ambivalence of color (valorized as formal purity or relation, devalorized as sensory matter, beauty on the one hand, attraction on the other, pure presence in both cases) is raised to the second power (squared) when it is the question of the color of the frame ..., when the parergonal equivocity of the color comes to intensify the parergonal equivocity of the frame. What would be the equivalent of this square for music? $?^{56}$

\section{White Noise}

A sound signal containing all frequencies within a given bandwidth. ${ }^{57}$

A pure white noise signal may only be produced by a generator called a white noise generator. ${ }^{58}$

Why does music that most moves us seem but an empty noise to the ear of a Carib? ?9 $^{59}$

There is a significance which I cannot fathom in the circumstance that the tones which seem rebellious to the negro's sense of intervallic propriety are the fourth and the seventh of the diatonic major series and the fourth, sixth and seventh of the minor. ${ }^{60}$

In the Essay on the Origin of Language Rousseau mocks Rameau's hypostatization of the rules of Harmony as the essence of music and the origin and source of its perfection and of the perfectibility of its effects, by drawing an analogy between that idea and those of an hypothetical country "where they had no idea of drawing, but where many people who spent their lives combining, mixing, grading colours, believed that they excelled in painting; those people would argue about our painting exactly as we argue about the music of the Greeks": remarking the large slabs of colour, for example, comparing colours and their combinations, and noting the beauty of their modulations, transitions, and vibrations. "Finally," he suggests "they might perhaps by dint of progress get to the experiment with the prism. Straightaway some famous artist would be sure to erect a fancy system on the basis of it": ${ }^{61}$ positing physical causes for the system of colours; primary colours from which all others could be derived; rules of relations between colours; and thereupon a system of the true principles of art.

56Derrida, The Truth in Painting, trans. Geoffrey Bennington and Ian McLeod (Chicago: Chicago University Press, 1987), 77.

57Philip Morehead and Anne McNeil, New American Dictionary of Music (New York: Dutton, 1991), 592.

58Truax, The World Soundscape Project's Handbook for Acoustic Ecology, 152.

59Rousseau, The First and Second Discourse with the Replies to Critics, 283.

60 Henry Edward Krehbiel, Afro-American Folksongs: A Study in Racial and National Music (New York: Schirmer, 1914), 73.

61 Rousseau, The First and Second Discourse with the Replies to Critics, 279. 
It was when I read this analogy between music and painting that it struck me:

1. That theories of Harmony - of tonality classical-style - make colour (tonality, pitch) the essential constituent of music, and the identification, differentiation, and control and containment of colour - the determination of its proper place with reference to the tonic (the root position, the home key, the neutral or white tone) - the source of music's dynamic, its principle/principal of movement and effect, "the lifeblood of the whole composition." 62

2. That this constitutive centrality of colour to (and colonization within) Western music is in fact figured in its most technical language in which chromatic, applies to:

Notes foreign to the mode or key, produced by the use of accidentals. ${ }^{63}$

Notes which do not belong to the diatonic scale. ${ }^{64}$

Those notes or chords which are passing between diatonic intervals. ${ }^{65}$

3. That this musical discourse of colour is explicitly racialized in that it is inscribed within and intersects with a narrative of tonal origins: of generation, hierarchy, propriety, purity, and place; of governance, dominance, order, and law. Heinrich Schenker is characteristically shameless in naming this (racialized) materiality (the sensory figure of racial purity) routinely concealed within the would-be neutrality of Western harmony. As in the examples already cited in which reference is made to the egotism of the tones, in which tonality is likened to a state or constitution, and in the following from Part I, Division I, Section I of Harmony subtitled: Tonal Systems: Their Origin and Differentiation with Regard to Position and Purity:

As in nature in general, so music manifests a procreative urge ... We should get used to seeing tones as creatures. We should learn to assume in them biological urges as they characterize human beings. ${ }^{66}$

4. That this narrative of ontogenesis (i.e., of the origin of individual tones) is in turn inscribed within a phylogenetic narrative of functional tonality itself as "the march of tonal progress," 67 which traces its evolution and development from its infancy to its full tonal maturity, indeed its perfection in Schenker's case, in the common practice period of Harmony classical-style. An evolution which is posited at the same time as a purification, a distillation, of the order and hierarchy of the One (the major mode) from and over the Many (a plurality

620swald Jonas, Introduction to Schenker's Harmony, xvii.

63 Collins Encyclopedia of Music, 125.

64 Compact Edition of the Oxford English Dictionary (Oxford: Oxford University Press, 1985), 409.

65 Jonas, Introduction to Schenker's Harmony, xvii.

66 Schenker, Harmony, 6.

67Norton, Tonality in Western Culture, 26. 
of modes), i.e., as the triumph of the neutral (White) One (in which no colouration is apparent) over what Norton describes as the "chaos of pitch."

For, if chromatic applies to notes foreign to the home key, to accidentals and passing notes, and notes which do not belong to the diatonic scale, then the home key, the fundamental tone, notes which are not accidental, which do not pass, which belong, and the diatonic scale itself must, like the white light of Reason, be White. Schenker tells us as much in The Occurrence of the Minor Mode among Primitive Peoples:

The primary musical impulses of man should be considered in comparison with songbirds, e.g. canaries, much more than under the aspect of artistic intention. The songbird knows of no diatony, no connection between determined tones. All he knows is a chaos of tones, a slurring and gargling and irrational trilling, which is deeply rooted in his animal emotions, especially in the erotic impulse. Primitive man likewise fashions but a chaos of indeterminate tones in accordance with his nature. Whether he is in love or arousing himself to a warlike mood, whether he dances or yields to his grief - no matter what emotion comes into play - the tones evoked are vague and approximate, whether taken individually or in their context. While it is easy to recognize the psychologic relationship between tones and emotions, it is much more difficult to find in them even as much as a trace of order ... It is one of the mystifying features of our art that its truth is not penetrated any more easily for having its roots in Nature! Today we know that the major mode has been, so to speak, designed and recommended by Nature; and yet we needed hecatombs of artists, a universe of generations and artistic experiments, to penetrate the secrets of Nature and attain her approval ... I would consider the minor mode as a steppingstone, perhaps the ultimate one or nearly so, leading up to the real and most solemn truth of Nature, i.e., the major mode. ${ }^{68}$ (my italics)

\section{Black Music}

Carmen. Opera in four acts by Georges Bizet (1828-75), composed in 1875 (libretto by Meilhac and Halévy, after a story by Merimée). The central figure is the passionate gypsy Carmen (soprano) who fascinates the sergeant Don José (tenor), leads him to mutiny, lures him to join a band of smugglers, abandons him in favour of the toreador (bull fighter) Escamillo (bass), and is finally stabbed to the heart by Don José in the moment when the victorious Escamillo emerges from the bull fight.

To this concise and exciting plot Bizet has written a music which, although in a "popular" vein, rises to greater heights of artistic perfection than hundreds of more ambitious and more "serious" operas. Although the music has been attacked as being "pseudo-Spanish" (which, in a way, it is), Carmen stands before the musical world as the inimitable incorporation of what the Spanish call flamenco. ${ }^{69}$ 
What interests me is how the systematic blanching or racialization of Western composition, "a decision made against the chaos of pitch," is enacted, performed, reproduced, and played out in what we actually hear, in what is actually composed in its terms. How chromaticism, that is, is put into play in Western music precisely as foreign, accidental, passing, not belonging: as a "bit of colour on the essential characteristics"; as, at one and the same time, a pleasure to be enjoyed and a threat of dis-order and dis-sonance to be managed and contained. Bizet's Carmen is exemplary in this respect.

The danger of immediate metaphors ... is that they are not always passing images; they push toward an autonomous kind of thought. ${ }^{70}$

The danger of Carmen's chromaticism (of chromaticism's Carmen or song) ${ }^{71}$ is that she (it) is not ever a passing image, ornament, supplement, ${ }^{72}$ or sound, secondary or subordinate to the essential characteristics of the home key (represented here by Don José), but is rather absolutely constitutive of (the) music itself, the "lifeblood of the whole composition" as Jonas observed, pushing inexorably, if tragically in this case, toward her own autonomous end(s). Don José's lyrical diatony which distinguishes him as the hero and her as the villain of this piece (the cause of what is routinely interpreted as his tragic end), though articulated to the principles of harmony and the institutions and ideals of religious, familial, and state law, is nevertheless completely inadequate to the power, force, and conviction of her somatic and sonic solicitations. ${ }^{73}$ For, in her reliance on what Rameau and Rousseau agree to exclude together ${ }^{74}$ from the essential constituents of music: rhythm, pitch, chromaticism, and vocal and bodily percussion, Carmen's music is irreducible to and thus beyond the mastery of the regulating principles of tonality classical-style, and which marks her within the terms of its own rhetoric as exotic, erotic, disruptive, dangerous, deadly, and dark. Not only is Carmen the gypsy, already marked as physically, legally and morally "dark"; her proper place is constituted as in and of the dark in the narrative: in the cigarette factory, the tavern, the dark night of intrigue and escape. In the bright sunlight of the town square Carmen is out of place: disruptive, trouble, in trouble and finally, of

70Bachelard, La formation de l'esprit scientifique, 4.

71 "Carmen (Latin) (1) Tune, song, strain, poem. (2) In fourteenth and fifteenth-century parlance, either the voice part of a composition that has also instrumental parts or the uppermost part of a composition for several voices" (Percy A. Scholes, The Oxford Companion to Music, 10th ed. [Oxford: Oxford University Press, 1974], 155).

72For a discussion of the complex aporetics of the supplement and the ornament, see Derrida, “...That Dangerous Supplement ...," in Of Grammatology, 141-64; and Derrida, The Truth in Painting, respectively.

73Following Derrida, I am exploiting the full etymological sense of the word "solicit," meaning to "shake the whole." See Derrida, "White Mythology: Metaphor in the Text of Mythology," 221, for example.

74 "One must move toward whatever it is that all the belligerent parties, at the height of the war now raging in the public arena, agree to exclude together. What does the unanimity of clienteles want to have nothing to do with? What does it desire to vomit?" (Derrida, "Ja, or the faux-band II," in Points ... Interviews, 1974-1994, trans. Peggy Kamuf et al., ed. Elisabeth Weber [Stanford, Calif.: Stanford University Press, 1995], 43). 
course, dead. But like a parasite (a foreign body which inhabits the interior), Carmen (the gypsy, the accidental and passing tone) cannot be destroyed without destroying the host: in this case the principle (the principal) and power of functional tonality itself.

A principle upon which everything is founded cannot be established too firmly; to lose sight of it for a moment is to destroy it. ${ }^{75}$

In the face of Carmen, Don José is completely disarmed and quickly loses sight (site) of the principles of harmony classical-style upon which the authority of his music and voice is based. Within its system, however, only one solution is possible to this (his) betrayal: the final solution (anticipated by Rameau in the admonition cited above in which "to lose sight of it for a moment is to destroy it") entailing the destruction of Carmen, the dark and dissonant passing tone who does not belong; the destruction of Don José, the neutral "white" tone of the home key, the sergeant seduced from his "loyalty to the tonic in the broadest sense of the term"; and the destruction of music itself. For, when she (chromaticism) dies, he (diatony) dies, and (the) opera too. ${ }^{76}$

It is 1875 , twelve years after the emancipation of the slaves in North America, and music is moving toward the end of tonality classical-style. It is the beginning of the end of white domination colonial-style and the beginning of the permeation of Western music by the rhythms, timbres, and tonalities of Black America, irreducible to and thus beyond the mastery of classical-style tonality.

Black music. White noise.

\section{Abstract}

This paper examines the links between Western music, Western metaphysics, and Western imperialism. Taking Derrida's reading of "White Mythology" and "Violence and Metaphysics" as its point of departure, the paper explores the relationship between the theories and practices of musical composition formalized in Europe in the eighteenth and finalized in the nineteenth century, and the theories and practices of race, racial differentiation, and empire that coincide(d) with it.

75Rameau, Treatise on Harmony, 10.

76 See McClary, Feminine Endings and Georges Bizet: Carmen, for a more sustained elaboration of the racial and sexual politics at stake in Bizet's Carmen. 